\title{
Effects of a 6-wk intraduodenal supplementation with quercetin on energy metabolism and indicators of liver damage in periparturient dairy cows
}

\author{
Ann-Kathrin Stoldt, ${ }^{*}$ Michael Derno, ${ }^{*}$ Gerd Nürnberg, $†$ Joachim M. Weitzel, $\ddagger$ Winfried Otten,§ \\ Alexander Starke,\# Siegfried Wolffram,Il and Cornelia C. Metges*1 \\ *Institute of Nutritional Physiology "Oskar Kellner," \\ †Institute of Genetics and Biometry, \\ łInstitute of Reproductive Biology, and \\ §Institute of Behavioural Physiology, Leibniz Institute for Farm Animal Biology (FBN), 18196 Dummerstorf, Germany \\ \#Clinic for Ruminants and Swine, Faculty of Veterinary Medicine, University of Leipzig, 04103 Leipzig, Germany \\ IIInstitute of Animal Nutrition and Physiology, Christian-Albrechts University of Kiel, 24118 Kiel, Germany
}

\begin{abstract}
Periparturient dairy cows experience metabolic challenges that result in a negative energy balance (EB) and a range of postpartum health problems. To compensate for the negative $\mathrm{EB}$, cows mobilize fatty acids from adipose tissues, which can lead to fatty liver disease, a periparturient metabolic disorder. Flavonoids, such as quercetin $(\mathrm{Q})$, are polyphenolic substances found in all higher plants and have hepatoprotective potential and the ability to prevent or reduce lipid accumulation in the liver. In ruminants, few studies on the metabolic effects of Q are available, and thus this study was conducted to determine whether $\mathrm{Q}$ has beneficial effects on EB, lipid metabolism, and hepatoprotective effects in periparturient dairy cows. Quercetin was supplemented intraduodenally to circumvent $\mathrm{Q}$ degradation in the rumen. Cows $(\mathrm{n}=10)$ with duodenal fistulas were monitored for $7 \mathrm{wk}$. Beginning 3 wk before expected calving, 5 cows were treated with $100 \mathrm{mg}$ of quercetin dihydrate per kilogram of body weight daily in a $0.9 \%$ sodium chloride solution for a total period of $6 \mathrm{wk}$, whereas the control cows received only the sodium chloride solution. The plasma flavonoid levels were higher in the Q-treated cows than in the control cows. A tendency for higher postpartum (pp) than antepartum (ap) plasma flavonoid levels was observed in the Q-treated cows than in the controls, which was potentially caused by a reduced capacity to metabolize Q. However, the metabolic status of the Q-treated cows did not differ from that of the control cows. The pp increases in plasma aspartate aminotransferase and glutamate dehydrogenase activities were less in the Q-treated cows than in the control cows. The Q had no effect on energy expenditures, but from ap to $\mathrm{pp}$
\end{abstract}

Received November 1, 2014.

Accepted March 14, 2015.

${ }^{1}$ Corresponding author: metges@fbn-dummerstorf.de the cows had a slight decline in respiratory quotients. Irrespective of the treatment group, the oxidation of fat peaked after calving, suggesting that the increase occurred because of an increased supply of fatty acids from lipomobilization. In conclusion, supplementation with Q resulted in lower pp plasma aminotransferase and glutamate dehydrogenase, which indicated reduced liver damage. However, the direct effects of $\mathrm{Q}$ on the liver and the implications for animal performance remain to be investigated.

Key words: transition dairy cow, quercetin, metabolism, liver health

\section{INTRODUCTION}

The periparturient period is defined as the $3 \mathrm{wk}$ before calving and the 3 wk after calving (Drackley, 1999) and is a period with enormous metabolic challenges for dairy cows that results in a range of postpartum health problems. After the onset of and during the first 40 to $80 \mathrm{~d}$ of lactation, the nutrient and energy requirements for milk production exceed energy intake, which leads to a negative energy balance (EB; Bell 1995; Coffey et al., 2002).

To compensate for the negative EB, cows mobilize FA from adipose tissue. Hallmarks of typical periparturient metabolic disorders (Goff and Horst, 1997; Gross et al., 2013), fatty liver disease and ketone body formation, occur if the uptake of NEFA in the liver exceeds the oxidation capabilities or the secretion of re-esterified triacylglycerol (TG) via very low-density lipoproteins, which are generally very low in ruminants (Bremmer et al., 2000). Fatty liver disease and negative EB are associated with a greater incidence of health problems such as mastitis, metritis, milk fever, ketosis, decreased reproductive performance caused by delayed uterine involution and ovarian activity, and impaired immune function (Staples and Thatcher, 1990; Bobe et al., 2004; Esposito et al., 2014). 
In the periparturient period, 40 to $60 \%$ of high-yielding dairy cows develop subclinical ketosis, whereas 2 to $15 \%$ and up to $40 \%$ develop clinical ketosis (McArt et al., 2012) and fatty liver disease (Bobe et al., 2004), respectively. These conditions reduce animal welfare and milk production and can lead to stock and economic losses, all of which negatively affect the profitability of farms (Suthar et al., 2013; McArt et al., 2015).

Phytochemicals that have potential benefits for the health of animals are commercially available, but studies that demonstrate their effectiveness are rare. Additionally, the increase in public concern with the use of pharmaceuticals in animal production requires a closer examination of the use of phytochemicals as alternatives to pharmaceuticals (Rochfort et al., 2008).

Flavonoids are polyphenolic substances found in all higher plants, including vegetables and grains (Nijveldt et al., 2001). Some flavonoids have hepatoprotective potential (Harborne and Williams, 2000), and quercetin $(\mathbf{Q})$ is one of the most potent flavonoids (Ader et al., 2000). Several studies, primarily with rodents and pigs, found decreased plasma lipid levels (Hoek-van den Hil et al., 2013; Jung et al., 2013; Wein and Wolffram, 2014) and prevention or reduction of lipid accumulation in the liver after Q treatment (Aguirre et al., 2011; Beltrán-Debón et al., 2011; Joven et al., 2012). The underlying mechanisms of these effects included an improvement in the $\Omega$ - and $\beta$-oxidation of $\mathrm{FA}$ in the liver and an upregulation of the genes involved in lipid metabolism (Kobayashi et al., 2010; Jung et al., 2013; Hoek-van den Hil et al., 2013). Additionally, Q had an effect on glucose metabolism and antidiabetic properties (Aguirre et al., 2011). For ruminants, information on the metabolic effects of $\mathrm{Q}$ is scarce. Although Q is largely degraded in the rumen, we recently reported that $\mathrm{Q}$ is bioavailable in cows after administration directly into the duodenum (Berger et al., 2012; Gohlke et al., 2013a). Therefore, in the present study, we investigated the potential metabolic effects of $\mathrm{Q}$ administered via a duodenal cannula, thereby circumventing degradation in the rumen. Our aim was to determine whether Q had metabolic effects during the periparturient phase in dairy cows by investigating the effects of $\mathrm{Q}$ on energy and lipid metabolism and milk production. We hypothesized that supplementation with duodenal $\mathrm{Q}$ in periparturient dairy cows would have beneficial effects on the EB and parameters of lipid metabolism and hepatoprotective function.

\section{MATERIALS AND METHODS}

\section{Animals and Diet}

The current study was conducted in compliance with German animal protection regulations and with approval of the authorities of the state of Mecklenburg-Vorpommern, Germany (Landesamt für Landwirtschaft, Lebensmittelsicherheit und Fischereiwesen Mecklenburg-Vorpommern, Germany; LALLF M-V/ TSD/7221.3-2.1-019/12).

German-Holstein cows $(\mathrm{n}=10 ;>9,000 \mathrm{~kg}$ of milk in first lactation) with an average BW of $759.9 \pm 25.7 \mathrm{~kg}$ (mean $\pm \mathrm{SE}$ ) were equipped with duodenal fistulas as previously described (Gohlke et al., 2013a). The cows were monitored for a total of $7 \mathrm{wk}$, beginning $4 \mathrm{wk}$ before the estimated date of their third calving. The animals had straw bedding in tiestalls, free access to water, and were offered a TMR for ad libitum intake. The composition of the diet was calculated in accordance with the recommendations of the German Society of Nutritional Physiology (GfE, 2001) with respect to gestation and lactation. The feed components and chemical composition of the TMR were determined according to the Weender standard procedure (Naumann and Bassler, 1993; Table 1). The DMI and milk yield were recorded daily. The milking frequency was twice daily at 0400 and $1430 \mathrm{~h}$, and the composition of the milk was determined weekly at the Landeskontrollverband für Leistungs-und Qualitätsprüfung Mecklenburg Vorpommern e.V. The EB was calculated according to Reist et al. (2002).

Beginning 3 wk before expected calving, 5 cows were supplied daily with $100 \mathrm{mg}$ of quercetin dihydrate (Carl Roth GmbH, Karlsruhe, Germany) per kilogram of BW for a total of 6 wk. The daily amount of $\mathrm{Q}$ was divided into 3 identical portions, mixed into a volume of 20 $\mathrm{mL}$ of $0.9 \% \mathrm{NaCl}$ solution (Serumwerk Bernburg AG, Bernburg, Germany) and was administered at 0630, 1200 , and $1800 \mathrm{~h}$ via the duodenal fistula. The control (CTR) cows $(\mathrm{n}=5)$ received the same volume of $0.9 \%$ $\mathrm{NaCl}$ solution without the Q. After calving, a cow of the CTR group developed clinical ketosis and 3 cows, 1 of the Q treated and 2 of the CTR group, retained placentas. The cows were treated appropriately.

\section{Respiration Measurements}

The cows were transferred to open-circuit respiration chambers (Derno et al., 2009) for measurements of energy expenditure at 4 wk antepartum (ap) before Q treatment and after 1 (2 wk ap) and 6 wk [3 wk postpartum ( $\mathbf{p p})$ ] of the $\mathrm{Q} / \mathrm{NaCl}$ treatment. A cow of the CTR group was too tall to fit in the chamber, and thus measurements were determined for only 9 cows.

The cows were halter-trained and acclimated to the chambers before the experiment. The cows were adapted once they began to eat, to lie down, and to ruminate in the chamber. On the afternoon before the respiration measurements, the cows were placed in the chambers 
Table 1. Ingredients and chemical composition of the diet (means $\pm \mathrm{SD}$ )

\begin{tabular}{|c|c|c|c|}
\hline \multirow[b]{2}{*}{ Item } & \multicolumn{3}{|c|}{ Amount } \\
\hline & Far-off $^{1}$ & Close-up ${ }^{2}$ & Early lactation ${ }^{3}$ \\
\hline \multicolumn{4}{|l|}{ Ingredient $(\mathrm{g} / \mathrm{kg}$ of $\mathrm{DM})$} \\
\hline Grass silage & 1,000 & $182.5 \pm 32.6$ & $211.8 \pm 14.7$ \\
\hline Corn silage & & $429.9 \pm 33.1$ & $356.1 \pm 25.5$ \\
\hline Grass hay & & $63.1 \pm 3.0$ & $43.5 \pm 23.7$ \\
\hline Straw & & $63.0 \pm 3.0$ & \\
\hline Soy extract meal & & $64.8 \pm 3.7$ & $58.9 \pm 39.7$ \\
\hline Corn, ground & & $31.6 \pm 1.1$ & $87.9 \pm 16.9$ \\
\hline Rape extract meal & & $68.1 \pm 22.0$ & $36.6 \pm 27.1$ \\
\hline Sugar beet pulp ${ }^{4}$ & & & $40.6 \pm 20.8$ \\
\hline Concentrate & & $92.9 \pm 24.4$ & $143.6 \pm 32.4$ \\
\hline Minerals $^{6}$ & & $11.4 \pm 1.3$ & $8.7 \pm 0.5$ \\
\hline Feed lime & & & $5.0 \pm 0$ \\
\hline \multicolumn{4}{|l|}{ Chemical composition } \\
\hline $\mathrm{DM}(\%)$ & $36.8 \pm 7.7$ & $43.1 \pm 0.9$ & $44.6 \pm 0.6$ \\
\hline $\mathrm{CP}(\% \mathrm{DM})$ & $18.3 \pm 1.3$ & $14.9 \pm 1.2$ & $16.2 \pm 0.6$ \\
\hline Crude fat ( $\%$ DM) & $3.7 \pm 0.6$ & $2.9 \pm 0.2$ & $2.8 \pm 0.1$ \\
\hline Crude fiber (\% DM) & $25.4 \pm 2.7$ & $20.8 \pm 0.4$ & $17.5 \pm 0.4$ \\
\hline $\mathrm{ME}(\mathrm{MJ} / \mathrm{kg}$ of $\mathrm{DM})$ & $10.7 \pm 0.6$ & $10.6 \pm 0.1$ & $11.1 \pm 0.1$ \\
\hline $\mathrm{NE}_{\mathrm{L}}(\mathrm{MJ} / \mathrm{kg}$ of $\mathrm{DM})$ & $6.4 \pm 0.4$ & $6.5 \pm 0.1$ & $7.0 \pm 0.1$ \\
\hline \multicolumn{4}{|c|}{${ }^{1} 6-3$ wk antepartum (ap); grass silage was fed ad libitum. } \\
\hline \multicolumn{4}{|c|}{${ }^{2} 3-1$ wk ap. } \\
\hline \multicolumn{4}{|c|}{${ }^{3} 1-3$ wk postpartum (pp). } \\
\hline \multicolumn{4}{|c|}{$\begin{array}{l}{ }^{4} \text { Arp (Thordsen, Rautenberg GmbH \& Co. KG, Sollerupmühle, Germany): } 7.3 \mathrm{MJ} \text { of } \mathrm{NE}_{\mathrm{L}} / \mathrm{kg} \text { of DM and } 153 \\
\text { g of utilizable protein } / \mathrm{kg} \text { of DM. }\end{array}$} \\
\hline \multicolumn{4}{|c|}{$\begin{array}{l}{ }^{5} \text { Concentrate MF } 2000 \text { (Vollkraft Mischfutterwerke GmbH, Güstrow, Germany): } 33 \% \text { extracted soy meal, } 20 \% \\
\text { corn, } 17 \% \text { wheat gluten, } 8 \% \text { extracted rapeseed meal, } 5 \% \text { sugar beet pulp, } 2 \% \text { sodium hydrogen carbonate, } \\
1.3 \% \text { calcium carbonate, } 0.2 \% \text { sodium chloride, } 8.0 \mathrm{MJ} \text { of } \mathrm{NE}_{\mathrm{L}} / \mathrm{kg} \text { of DM, and } 204 \mathrm{~g} \text { of utilizable protein } / \mathrm{kg} \\
\text { of DM. }\end{array}$} \\
\hline \multicolumn{4}{|c|}{$\begin{array}{l}{ }^{6} \text { Rinderstolz } 9522 \text { lactation (Salvana Tiernahrung GmbH, Sparrieshoop, Germany): } 92 \% \text { crude ash, } 20 \% \text { cal- } \\
\text { cium, } 5 \% \text { phosphorus, } 6 \% \text { magnesium, } 8 \% \text { sodium, and retinol, } \beta \text {-carotene, } 25 \text {-OH-vitamin } \mathrm{D}_{3} \text {, and DL- } \alpha \text { - } \\
\text { tocopherolacetate. }\end{array}$} \\
\hline
\end{tabular}

and were provided with rations. Drinking water was freely available throughout the study.

The gas exchange measurements began at $0630 \mathrm{~h}$ and the concentrations of $\mathrm{CO}_{2}, \mathrm{O}_{2}$, and $\mathrm{CH}_{4}$ were measured at 6-min intervals throughout $23.9 \mathrm{~h}$; the data were normalized to $24 \mathrm{~h}$. The feed intake and physical activity were measured continuously for each individual cow, and the production of $\mathrm{CO}_{2}$ and $\mathrm{CH}_{4}$ and the consumption of $\mathrm{O}_{2}$ were calculated as previously described (Derno et al., 2013).

Within the respiration chamber, technicians wearing face masks connected to the outside chamber air via flexible tubes to prevent adulteration of the gas exchange measurements performed the administration of $\mathrm{Q}$ or $\mathrm{NaCl}$, daily milking, and measurements of rectal body temperature. The cows were milked at 0630 and $1630 \mathrm{~h}$; the milk yield and body temperature were recorded daily. The measurements of body mass were recorded before and after stays in the respiration chambers. The heat production, fat oxidation (FOX), carbohydrate oxidation (COX), and respiratory quotient (RQ) were calculated as previously described (Derno et al., 2013).

\section{Blood Sampling}

Blood samples were drawn from the left jugular vein by venipuncture every week of the study on Monday, Wednesday, and Friday at $1200 \mathrm{~h}$ using the vacutainer system (Becton, Dickinson and Company, Plymouth, UK). Similarly, the blood samples for flavonoid analysis were collected weekly on Mondays (0800 and $1200 \mathrm{~h}$ ) and on Fridays at $1200 \mathrm{~h}$. Lithium-Heparin vacutainers $(10 \mathrm{~mL})$ were used to prepare plasma for the analysis of flavonoid concentrations; potassium-EDTA vacutainers $(10 \mathrm{~mL})$ were used for all other plasma parameters.

When in the respiration chambers, blood samples were collected from the cows through a catheter using potassium-EDTA monovettes $(9 \mathrm{~mL}$; Sarstedt AG \& Co., Nümbrecht, Germany). The day before respiration measurements, all cows were equipped with a jugular vein catheter (Certofix Mono; B. Braun Melsungen AG, Melsungen, Germany), which was fixed with 2 stitches and a bandage (Optiplaste C; BSN medical S.A.S., Vibraye, France) and was connected to $2 \mathrm{~m}$ of tubing (original perfusor tubing; B. Braun Melsungen AG) to collect blood samples from outside the chamber. 


\section{Sample Processing and Analyses}

The blood samples were immediately centrifuged at $1,500 \times g$ at $4^{\circ} \mathrm{C}$ for $20 \mathrm{~min}$, and the plasma aliquots were stored at $-80^{\circ} \mathrm{C}$. The concentrations of glucose, cholesterol, TG, NEFA, BHBA, albumin, urea, aspartate aminotransferase (AST), glutamate dehydrogenase (GLDH), and creatine kinase (CK) were analyzed at the clinic for cattle of the Stiftung Tierärztliche Hochschule, Hannover, Germany, and at the Institute of Nutritional Physiology at the Leibniz Institute for Farm Animal Biology (FBN), Dummerstorf, Germany, with an automatic enzymatic analyzer (ABX Pentra 400; Horiba Medical, Montpellier, France) using commercial kits [glucose: Kit No. 553-230, cholesterol: Kit No. 553-127, and AST: Kit No. 553-256 G (MTI Diagnostics, Idstein, Germany); TG: Kit No. A11A01640 (ABX-Horiba Medical); NEFA: Kit No. 600-215S or Kit No. 434-91795/436-91995 (Wako Chemicals GmbH, Neuss, Germany); BHBA: Kit No. RB1007, urea: Kit No. LT-UR 0050 or 0010 (Labor \& Technik Eberhart Lehmann GmbH, Berlin, Germany); GLDH: Kit No. 11929992216 (Roche Diagnostics GmbH, Mannheim, Germany); albumin: Kit No. A11A01664, CK: Kit No. A11A01632 (Axon Lab AG, Reichenbach, Germany)]. The albumin and CK were measured only once a week on Wednesdays. The glucagon was analyzed at the Institute of Reproductive Physiology at the Leibniz Institute for Farm Animal Biology using a commercial RIA (Kit Ref RIA-1258; DRG Instruments GmbH, Marburg, Germany).

The plasma concentrations of adrenaline and noradrenaline were determined at the Institute of Behavioral Physiology at the Leibniz Institute for Farm Animal Biology with HPLC using electrochemical detection as previously described (Weber et al., 2013). To inhibit the breakdown of catecholamines, semicarbazid was added to the monovettes before sampling the blood. The glucagon and catecholamine concentrations were measured on only the days of the respiration measurements.

The plasma flavonoid content was analyzed at the Institute of Animal Nutrition and Physiology of Christian-Albrechts-University, Kiel, Germany, as previously described (Gohlke et al., 2013a). The plasma $\mathrm{Q}$ and $\mathrm{Q}$ metabolites with an intact flavonol structure (kaempferol, tamarixetin, and isorhamnetin) were measured individually; the flavonol concentrations presented in the current paper are total flavonoids, calculated as the sum of the concentrations of $\mathrm{Q}$ and its metabolites.

\section{Statistical Analyses}

The data were analyzed statistically with SAS/STAT 9.3 (SAS Institute Inc., Cary, NC) using repeatedmeasures ANOVA (PROC MIXED). The factors were $\mathrm{Q}$ (yes or no), day relative to calving and the $\mathrm{Q} \times$ day interaction. The covariance structure of the repeated factor day was modeled by autoregressive first-order [AR (1)]. The basal, ap, and pp periods were evaluated separately. The effects were significant at $P \leq 0.05$, and the differences between treatments (Q or CTR) were compared with the Tukey-Kramer tests. The data are presented as least squares means \pm standard error. Because the interaction effects in the analysis of respiration measurements were not significant, they were removed from the final model.

\section{RESULTS}

\section{Zootechnical Data}

The Q treatment had no effect on BW, but BW decreased $(P<0.001)$ in both groups, from $759.9 \pm 25.7$ $\mathrm{kg}$ at $4 \mathrm{wk}$ ap to $601 \pm 25.4 \mathrm{~kg}$ at $3 \mathrm{wk}$ pp. The DMI was not different between the Q-treated and control groups and between 4 wk ap $(10.4 \pm 1.2 \mathrm{~kg} / \mathrm{d})$ and wk 1 ap $(9.6 \pm 1.1 \mathrm{~kg} / \mathrm{d} ; P>0.4)$; however, the DMI increased $(P<0.05)$ after calving $(13.8 \pm 1.1 \mathrm{~kg} / \mathrm{d})$ at 2 wk pp. The feed energy intake was higher $(P$ $<0.05)$ after calving in both groups, increasing from $60.6 \pm 8.8 \mathrm{MJ}$ of $\mathrm{NE}_{\mathrm{L}} / \mathrm{d}$ at $4 \mathrm{wk}$ ap to $89.7 \pm 8.3 \mathrm{MJ}$ of $\mathrm{NE}_{\mathrm{L}} / \mathrm{d}$ at 2 wk pp. The composition of the milk was not affected $(P>0.05)$ by the $\mathrm{Q}$ supplementation. The milk yield increased $(P<0.001)$, although no difference was found between the $\mathrm{Q}$ and CTR cows, from $24.3 \pm 3.5 \mathrm{~kg} / \mathrm{d}$ in the first week of lactation to $32.7 \pm 2.6 \mathrm{~kg} / \mathrm{d}$ on d $19 \mathrm{pp}$. The latter value for milk yield corresponded to $33.9 \pm 3.2 \mathrm{~kg} / \mathrm{d}$ of ECM. The milk protein levels decreased $(P<0.001)$ in the first 3 wk of lactation from d 3 pp with $4.4 \pm 0.2 \%$ to 2.9 $\pm 0.2 \%$ on d $18 \mathrm{pp}$, which corresponded to $1.1 \pm 0.1$ and $1.0 \pm 0.1 \mathrm{~kg}$ of milk protein $/ \mathrm{d}$, respectively $(P$ $=0.8)$. No change $(P=0.5)$ was detected in milk fat concentration with time, which was $5.3 \pm 0.3 \%$ in the first $3 \mathrm{wk}$ of lactation. The lactose concentration in milk increased $(P<0.001)$ with $4.2 \pm 0.1 \%$ on d $3 \mathrm{pp}$ to $4.7 \pm 0.1 \%$ on $\mathrm{d} 18 \mathrm{pp}$, which corresponded to 1.0 \pm 0.1 and $1.5 \pm 0.1 \mathrm{~kg}$ of lactose/d, respectively. The $\mathrm{EB}$ ap and pp was not affected by the Q treatment but was lower $(P<0.001)$ after calving than before and reached negative values with a nadir of $-55.5 \pm$ 17.6 MJ of $\mathrm{NE}_{\mathrm{L}} / \mathrm{d}$ on d 9 pp. 


\section{Plasma Flavonoids}

The major flavonoid in plasma was $\mathrm{Q}$ with minor levels of kaempferol, tamarixetin, and isorhamnetin (data not shown). The total plasma flavonoid concentrations were higher $(P<0.05)$ in the $\mathrm{Q}$-treated cows than in the CTR cows on Mondays and Fridays at 1200 $\mathrm{h}$ throughout the 6-wk period of Q supplementation $(166.9 \pm 23.4$ vs. $5.2 \pm 24.1 \mathrm{nmol} / \mathrm{L}$, respectively; Figure $1)$. The concentrations were higher at $0800(P<0.05)$ than at $1200 \mathrm{~h}(357.3 \pm 42.9$ vs. $164.0 \pm 27.8 \mathrm{nmol} / \mathrm{L}$, respectively). A trend toward a higher 1200-h plasma flavonoid concentration pp than ap was observed (242.1 \pm 49.7 vs. $96.9 \pm 49.7 \mathrm{nmol} / \mathrm{L}$, respectively; $P=0.09$ ), an increase that was equivalent to $150 \%$ higher plasma flavonoid concentration after calving. By contrast, the plasma flavonoid levels at $0800 \mathrm{~h}(1.5 \mathrm{~h}$ after the first daily dose at $0630 \mathrm{~h}$ ) tended to be lower pp than ap $(194.46 \pm 99.9$ vs. $410.3 \pm 96.1 \mathrm{nmol} / \mathrm{L}$, respectively; $P=0.08)$.

\section{Plasma Metabolites, Enzymes, and Hormones}

The base levels of plasma metabolites, hormone concentrations, and enzyme activities were not different between the cow groups before the start of the $\mathrm{Q}$ supplementation, although plasma AST activity had a tendency to be higher in the CTR cows $(P=0.053$; Table 2). A significant treatment $\times$ day interaction was detected for only glucose in the ap period. With the exception of plasma AST activity, the metabolite and hormone concentrations were not affected by the $\mathrm{Q}$ treatment, but some were influenced by day relative to calving (Table 2). The plasma NEFA concentrations increased from basal values to calving and then increased $(P<0.05)$ further pp until $21 \mathrm{~d}$ after calving. The plasma BHBA levels showed no difference between the Q-treated cows and the CTR cows, but there was an increase from basal values to calving and then a further increase immediately after calving $(P$ $<0.05)$. The plasma TG and glucose levels decreased $(P<0.05)$ after the onset of lactation. The plasma cholesterol levels decreased from basal values to calving $(P<0.05)$ and then increased pp $(P<0.05)$ from a nadir shortly after calving; lower values were observed in the pp period than in the ap period. The plasma noradrenaline concentrations increased $(P<0.05)$ from wk 2 ap to wk 3 pp $(220.5 \pm 36.1$ vs. $301.9 \pm 34.7$ ng/L, respectively). For the liver enzymes, the plasma AST activity showed an effect of the intraduodenal Q administration during both ap $(P<0.05)$ and pp $(P<$ $0.05)$ periods, with higher values in CTR cows and an increase $(P<0.05)$ in both groups beginning $1 \mathrm{~d}$ after calving; an increase that was much more pronounced in the CTR cows (Figure 2). By contrast, the plasma GLDH (Figure 3) and CK activities did not differ $(P>$ $0.05)$ between the groups.

\section{Energy Expenditure}

The measures of energy expenditure were not affected by Q supplementation but showed time effects relative to calving. The daily heat production increased $(P<0.001)$ from $823.7 \pm 32.6 \mathrm{~kJ} / \mathrm{kg}$ of $\mathrm{BW}^{0.75}$ at $4 \mathrm{wk}$ ap (before Q supplementation) to $987.6 \pm 32.5 \mathrm{~kJ} / \mathrm{kg}$ of $\mathrm{BW}^{0.75}$ at 3 wk pp, whereas the RQ decreased $(P<$ $0.05)$ from $4 \mathrm{wk}$ ap to $3 \mathrm{wk}$ pp $(0.82 \pm 0.02$ vs. $0.80 \pm$ 0.02 , respectively). The calculated FOX increased $(P<$ $0.05)$ from 4 wk ap $\left(466.8 \pm 61.2 \mathrm{~kJ} / \mathrm{kg}\right.$ of $\left.\mathrm{BW}^{0.75}\right)$ to $607.8 \pm 60.9 \mathrm{~kJ} / \mathrm{kg}$ of $\mathrm{BW}^{0.75}$ at 3 wk pp. Similarly, the COX increased $(P<0.05)$ from $384.4 \pm 85.5 \mathrm{~kJ} / \mathrm{kg}$ of $\mathrm{BW}^{0.75}$ at $4 \mathrm{wk}$ ap to $403.0 \pm 85.2 \mathrm{~kJ} / \mathrm{kg}$ of $\mathrm{BW}^{0.75}$ at 3 wk pp, but the highest COX values were found at $2 \mathrm{wk}$ ap with $466.3 \pm 87.6 \mathrm{~kJ} / \mathrm{kg}$ of $\mathrm{BW}^{0.75}$.

The production of methane was higher $(P<0.05)$ at 3 wk pp $(380.0 \pm 36.7 \mathrm{~L} / \mathrm{d})$ than at 4 wk ap $(313.1 \pm$ $36.7 \mathrm{~L} / \mathrm{d}$ ) and was not affected in the Q-treated cows. By contrast, when related to DMI at 4 wk ap, the production of methane was higher $(P<0.05)$ than at $3 \mathrm{wk}$ pp $(37.9 \pm 1$. vs. $30.7 \pm 1.5 \mathrm{~L} / \mathrm{kg}$ of DMI, respectively).

\section{DISCUSSION}

In a previous study by our group (Gohlke et al., 2013a) with a single dose of $27 \mathrm{mg}$ of $\mathrm{Q} / \mathrm{kg}$ of $\mathrm{BW}$ per day, the baseline plasma flavonoid values were reached $4 \mathrm{~h}$ after intraduodenal administration. In the present study we used $100 \mathrm{mg}$ of $\mathrm{Q} / \mathrm{kg}$ of BW per day, administered in 3 daily aliquots, to generate a constantly elevated level of plasma flavonoids throughout the day. This amount of $\mathrm{Q}$ resulted in higher levels of plasma flavonoids in the Q-treated than in the CTR cows $5.5 \mathrm{~h}$ (1200-h samples) after administration of the morning aliquot. Based on the decrease in flavonoid concentration between 0800 and $1200 \mathrm{~h}$, it was assumed that plasma flavonoids were still significantly elevated at least $5.5 \mathrm{~h}$ after the last dosing (0600 h; i.e., until approximately midnight, and possibly longer). Thus, the dosing scheme used in the present study likely elevated levels of plasma flavonoids during at least 18 of $24 \mathrm{~h}$.

The concentrations of plasma flavonoids at $1200 \mathrm{~h}$ were higher pp than ap, which suggested an effect of the stage of lactation, the status of the liver, or both on total plasma flavonoid concentrations. The liver is particularly important for the elimination of $\mathrm{Q}$ and its metabolites (Lesser and Wolffram, 2006). The 

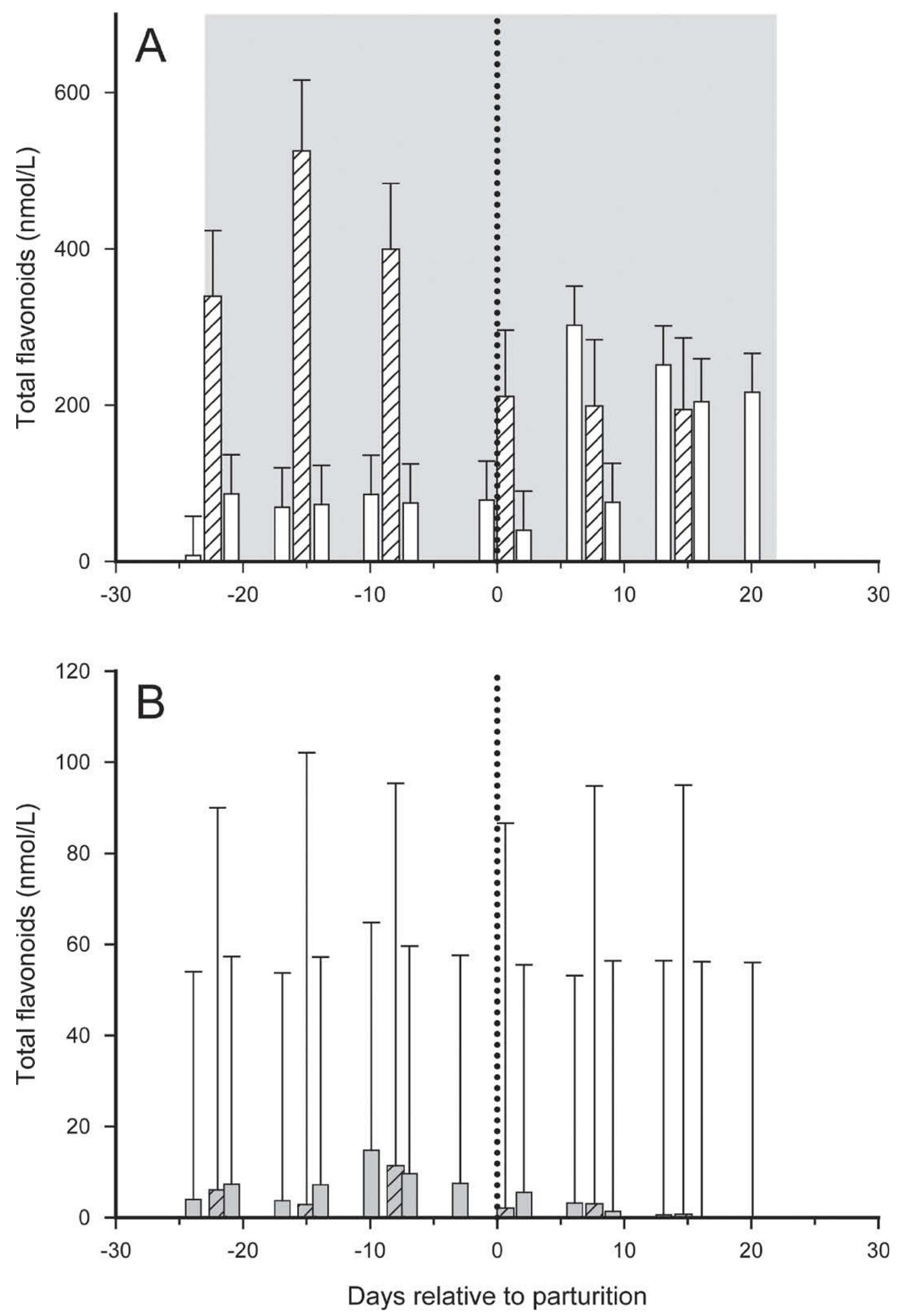

Figure 1. Concentrations of total flavonoids in plasma of cows with (A) or without (B) intraduodenal quercetin (Q) supplementation in the periparturient period. The shaded area indicates intraduodenal Q supplementation from wk -3 to 3 relative to calving. A total amount of 100 mg of quercetin dihydrate per kilogram of BW was given daily in 3 equal doses at 0630,1200 , and $1800 \mathrm{~h}$. Values are LSM \pm SE of $\mathrm{n}=5$ cows per group. The day of calving is the dotted vertical line. Blood samples were collected on Mondays at 0800 (hatched bars) and $1200 \mathrm{~h}$ (plain bars) and on Fridays at $1200 \mathrm{~h}$ (plain bars). The 1200-h samples were collected before administering the 1200-h dose of Q. Please note the different scaling for treatment (A) and control (B) groups. 
Table 2. Plasma levels of metabolites, hormones and enzymes before (basal) and during quercetin (Q) supplementation from 3 wk before to 3 wk after parturition in cows ${ }^{1}$

\begin{tabular}{|c|c|c|c|c|}
\hline \multirow[b]{2}{*}{ Item } & \multicolumn{2}{|c|}{ Group } & \multicolumn{2}{|c|}{$P$-value } \\
\hline & Quercetin & Control & Treatment & Day \\
\hline $\mathrm{ap}^{3}$ & $235.3 \pm 60.8$ & $274.4 \pm 67.2$ & 0.675 & 0.019 \\
\hline $\mathrm{pp}^{4}$ & $889.3 \pm 131.6$ & $954.9 \pm 120.4$ & 0.719 & 0.003 \\
\hline \multicolumn{5}{|c|}{ BHBA (mmol/L) } \\
\hline $\mathrm{pp}$ & $1.4 \pm 0.4$ & $2.3 \pm 0.3$ & 0.136 & 0.370 \\
\hline \multicolumn{5}{|c|}{ Triglycerides (mmol/L) } \\
\hline Basal & $0.2 \pm 0.0$ & $0.2 \pm 0.0$ & 0.674 & 0.707 \\
\hline ap & $0.2 \pm 0.0$ & $0.2 \pm 0.0$ & 0.708 & 0.172 \\
\hline pp & $0.1 \pm 0.0$ & $0.1 \pm 0.0$ & 0.382 & 0.023 \\
\hline \multicolumn{5}{|c|}{ Cholesterol $(\mathrm{mmol} / \mathrm{L})$} \\
\hline Basal & $2.9 \pm 0.3$ & $2.5 \pm 0.3$ & 0.398 & 0.148 \\
\hline \multicolumn{5}{|c|}{ Glucose (mmol/L) } \\
\hline pp & $2.8 \pm 0.1$ & $2.7 \pm 0.1$ & 0.499 & 0.006 \\
\hline \multicolumn{5}{|c|}{ Albumin (g/L) } \\
\hline Basal & $32.7 \pm 1.0$ & $33.5 \pm 1.0$ & 0.553 & ${ }^{6}$ \\
\hline ap & $31.1 \pm 0.7$ & $30.4 \pm 0.7$ & 0.526 & 0.679 \\
\hline pp & $31.0 \pm 1.2$ & $30.5 \pm 1.1$ & 0.784 & 0.494 \\
\hline \multicolumn{5}{|c|}{ Urea $(\mathrm{mmol} / \mathrm{L})$} \\
\hline Basal & $4.4 \pm 0.4$ & $3.8 \pm 0.5$ & 0.405 & 0.049 \\
\hline ap & $4.3 \pm 0.5$ & $4.4 \pm 0.5$ & 0.869 & 0.439 \\
\hline pp & $3.7 \pm 0.4$ & $3.2 \pm 0.3$ & 0.361 & 0.116 \\
\hline \multicolumn{5}{|c|}{ Aspartate aminotransferase $(\mathrm{U} / \mathrm{L})$} \\
\hline Basal & $61.6 \pm 7.4$ & $85.1 \pm 7.4$ & 0.053 & 0.178 \\
\hline ap & $60.6 \pm 4.5$ & $86.4 \pm 5.0$ & 0.004 & 0.210 \\
\hline pp & $93.5 \pm 14.2$ & $170.4 \pm 13.7$ & 0.003 & 0.007 \\
\hline \multicolumn{5}{|c|}{ Glutamate dehydrogenase (U/L) } \\
\hline ap & $134.5 \pm 21.9$ & $112.4 \pm 26.9$ & 0.541 & $-^{8}$ \\
\hline pp & $92.7 \pm 23.5$ & $111.8 \pm 24.5$ & 0.591 & ${ }^{8}$ \\
\hline \multicolumn{5}{|c|}{ Adrenaline ${ }^{7}(\mathrm{ng} / \mathrm{L})$} \\
\hline Basal & $44.6 \pm 9.0$ & $31.2 \pm 10.1$ & 0.354 & $-^{6}$ \\
\hline ap & $27.9 \pm 3.2$ & $20.3 \pm 4.1$ & 0.157 & -8 \\
\hline $\mathrm{pp}$ & $27.8 \pm 3.2$ & $21.3 \pm 3.6$ & 0.209 & $-^{8}$ \\
\hline \multicolumn{5}{|c|}{$\begin{array}{l}\text { pp } \\
\text { Noradrenaline }^{7}(\mathrm{ng} / \mathrm{L})\end{array}$} \\
\hline Basal & $235.2 \pm 42.5$ & $203.3 \pm 47.5$ & 0.633 & $-^{6}$ \\
\hline ap & $241.4 \pm 46.3$ & $199.5 \pm 55.3$ & 0.575 & -8 \\
\hline $\mathrm{pp}$ & $286.8 \pm 46.3$ & $316.9 \pm 51.7$ & 0.676 & $-^{8}$ \\
\hline
\end{tabular}

${ }^{1}$ Values are LSM $\pm \mathrm{SE} ; \mathrm{n}=5$ per group.

${ }^{2}$ Values of week before start of quercetin (or $\mathrm{NaCl}$ ) supplementation.

${ }^{3}$ Ant partum (ap); mean values of treatments 3 wk before calving.

${ }^{4}$ Postpartum (pp); mean values of treatments 3 wk after calving.

${ }^{5}$ Interaction of treatment $\times$ day; $P$-value $<0.05$.

${ }^{6}$ Only one sample before quercetin supplementation.

${ }^{7}$ Plasma glucagon and catecholamine concentrations are from days of respiration measurements only.

${ }^{8}$ Only one sample in time period. 


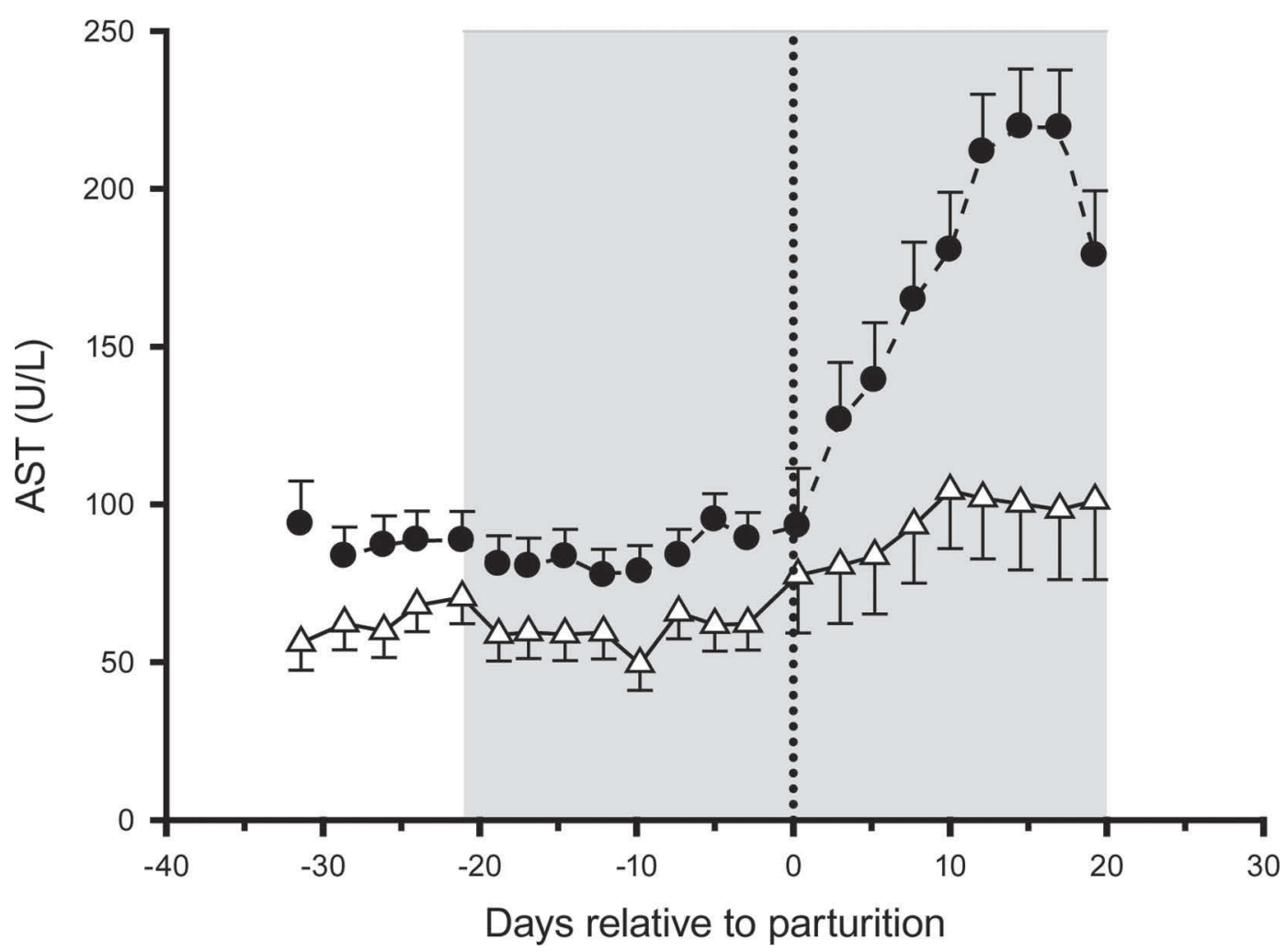

Figure 2. Plasma aspartate aminotransferase (AST) activity levels in cows with ( $\Delta$; solid line) or without (-; dashed line) intraduodenal quercetin supplementation in the periparturient period. Values are LSM \pm SE of $n=5$ cows per group. The shaded area indicates the period of quercetin supplementation from wk -3 to 3 , relative to calving. The day of calving is the dotted vertical line.

metabolism and elimination of drugs in the liver can be impaired in early-lactating cows (Lake et al., 2011; Merrell and Cherrington, 2011); thus, it is possible that the capacity to metabolize $\mathrm{Q}$ in the liver was reduced pp, which could explain the higher plasma Q concentrations pp. However, at $0800 \mathrm{~h}$ we observed lower levels of plasma $\mathrm{Q}$ pp than ap, which could be attributed to a lower absorption of $\mathrm{Q}$ due to faster passage through the digestive tract after calving (Aikman et al., 2008).

Similar to the effects on cows in midlactation (Gohlke et al., 2013b), chronic administration of Q had no effect on DMI, milk yield, or BW. However, in contrast to our previous finding of increased milk protein in midlactation Q-treated cows (Gohlke et al., 2013b), we detected no changes in milk protein in the present study. Whether this result was due to the stage of lactation or another reason is not clear at present. As expected, the EB decreased after calving and reached a nadir $9 \mathrm{~d}$ pp, largely caused by the increase in milk yield.

In previous studies, Q lowered concentrations of plasma lipids (Hoek-van den Hil et al., 2013; Jung et al., 2013; Wein and Wolffram, 2014), which was explained by the upregulation of genes involved in $\beta$ - and $\Omega$-FA oxidation and by the downregulation of ketogenic genes
(Kobayashi et al., 2010). However, in contrast to our hypothesis, the Q treatment did not improve metabolic status compared with that of the control cows. The concentrations of plasma NEFA and BHBA are indicators of energy status and lipomobilization (Cozzi et al., 2011) and are highly associated with hepatic lipidosis (Mostafavi et al., 2013). According to Duffield et al. (2009) and Gonzalez et al. (2011), high lipomobilization is characterized by NEFA $>400 \mu \mathrm{mol} / \mathrm{L}$ and subclinical ketosis is characterized by BHBA $>1.2 \mathrm{mmol} / \mathrm{L}$. In our study, the cows had greater concentrations of NEFA and BHBA after calving (>850 and $>1.3 \mathrm{mmol} / \mathrm{L}$, respectively), which indicated that they suffered from subclinical ketosis. As found in other studies, the levels of plasma glucose were lower pp than ap, which indicated the use of glucose for milk production and thus low availability of systemic glucose (Bell, 1995; Djokovic et al., 2009; Cozzi et al., 2011; Weber et al., 2013). The plasma concentrations of TG, cholesterol, albumin, and urea are indicators of liver function and biosynthetic capacity, which are reduced in cases of fat infiltration and hepatocyte degeneration (Djokovic et al., 2009, 2013). After calving, we found lower levels of plasma TG and cholesterol. Reduced levels of 


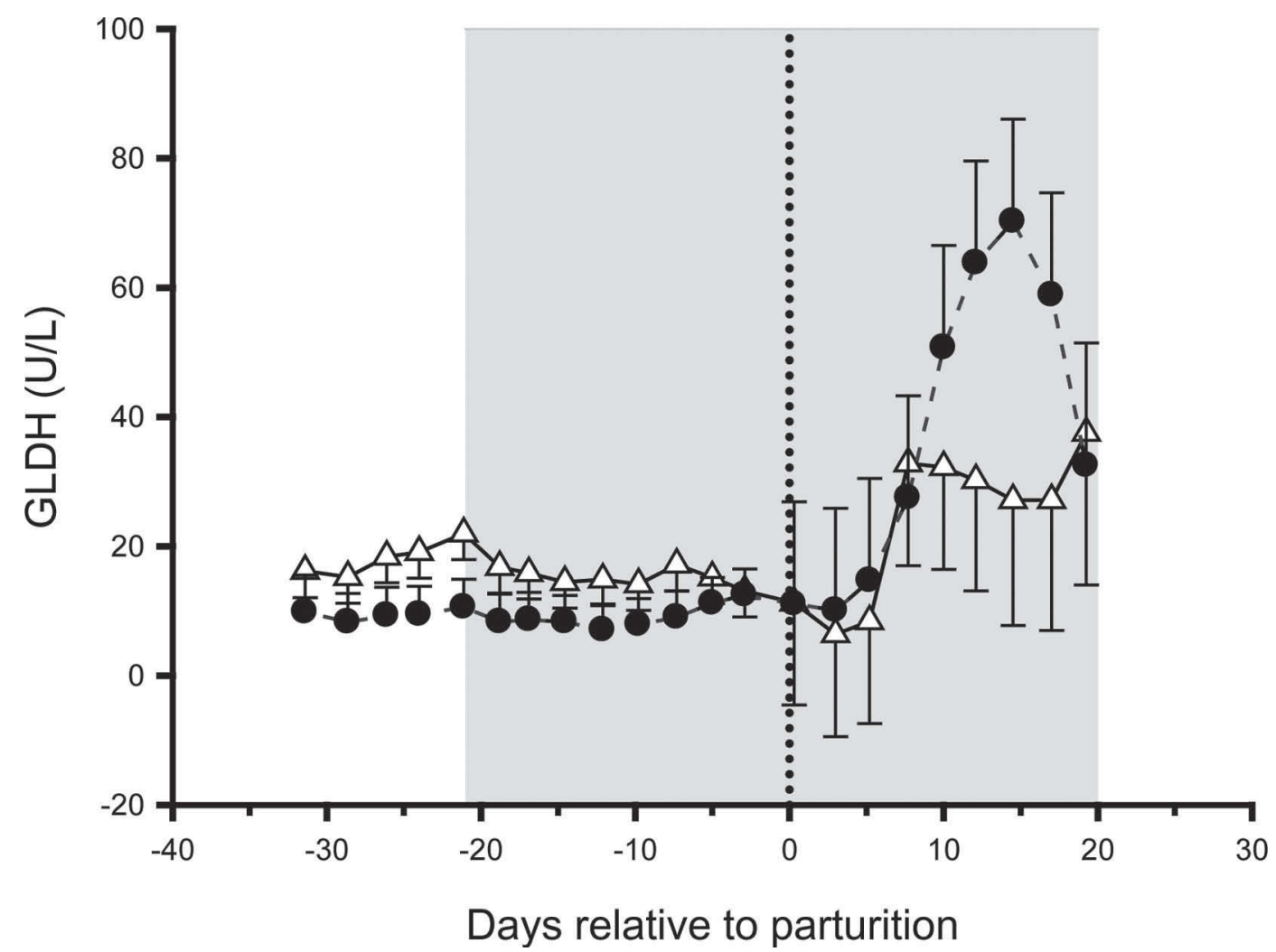

Figure 3. Plasma glutamate dehydrogenase (GLDH) activity levels in cows with ( $\triangle$; solid line) or without (@; dashed line) intraduodenal quercetin supplementation in the periparturient period. Values are LSM \pm SE of $n=5$ cows per group. The shaded area indicates the period of quercetin supplementation from wk -3 to 3 relative to calving. The day of calving is the dotted vertical line.

plasma albumin and urea may indicate liver cell damage (Grummer, 1993; Djokovic et al., 2009), but we did not find any changes in plasma albumin or urea. The catecholamines provoke lipolysis, particularly during lactation (Vernon, 2005). Increased nutrient intake stimulates the sympathetic nervous system and, thus, the action of noradrenaline, which is accompanied by increases in thermogenesis (Landsberg, 2006). This relationship was consistent with the increase in plasma values of noradrenaline from ap to $\mathrm{pp}$ and the higher heat production pp in cows in the present study.

To investigate liver damage, we measured the activities of AST and GLDH in plasma. Severe fat infiltration causes hepatocyte destruction with the subsequent release of the cytosolic enzyme AST (Liu et al., 2012). Plasma AST values above $100 \mathrm{U} / \mathrm{L}$ indicate hepatic lesions and a fatty liver (Gonzalez et al., 2011; Mostafavi et al., 2013). By contrast, GLDH is specifically expressed in the liver and increased levels in plasma suggest hepatocyte death or sublethal injury (Ok et al., 2013). Both the Q-treated and CTR cows in this experiment showed an increase in levels of plasma AST from ap to pp. Before Q supplementation, the plasma AST tended to be higher in the CTR cows but re- mained within the normal range ap (Thurmann, 2012). The increase in AST values pp was considerably less in the Q-treated cows than in the CTR cows. This observation was similar to findings for mice and rats with nonalcoholic steatohepatitis and cirrhosis, respectively, in which Q supplementation inhibited the development of steatosis and reduced levels of AST (Peres et al., 2000; Marcolin et al., 2013). Because AST is not liverspecific, we also measured the plasma activity of CK (Kalaitzakis et al., 2010). With CK activity, no difference between the CTR and Q-treated cows was detected, leading us to conclude that the observed effects in regard to AST values were not caused by a release from muscle cells. Thus, our observations were solely because of differences in liver damage between the groups. Plasma GLDH concentrations, by contrast, were not affected by the Q treatment after calving. However, in the CTR cows, the numerical increase in plasma GLDH values from ap to pp was approximately $300 \%$, whereas in the Q-treated cows the increase was only 50\% ( $P$ $<0.15$ ), which indicated that $\mathrm{Q}$ supplementation also had a potential hepatoprotective effect with respect to GLDH values. An explanation for why the effect of $\mathrm{Q}$ was more apparent with plasma AST than GLDH 
could be that GDLH is a mitochondrial enzyme that is only elevated with complete cell destruction, whereas AST is a hepatocellular leakage enzyme released from the cytosol through cell damage (Ok et al., 2013).

The reported effects of $\mathrm{Q}$ and other flavonols on energy expenditure in humans (Dulloo et al., 1999; Hursel et al., 2011) and mice (Stewart et al., 2008) are inconsistent (Klaus et al., 2005; Egert et al., 2011). We measured several components of energy metabolism via indirect calorimetry but did not detect effects of Q on energy expenditure. Nevertheless, from the ap to pp period, energy expenditure increased in both groups because of the onset of milk production (Jentsch et al., 2001). The RQ is indicative of changes in oxidative substrate and ranges from 1.0, which represents pure carbohydrate oxidation, to 0.7 for pure fat oxidation (Kim et al., 2013). The cows in our study showed a slight decline in RQ from wk 4 ap to wk $3 \mathrm{pp}$; furthermore, FOX peaked at 3 wk pp. These results suggest an increase in FA oxidation that reflected the greater supply of FA as an energy source from lipomobilization after calving (Dulloo et al., 1999; Börner et al., 2013).

Together, our results confirmed the typical changes that occur in energy, nutrient, and liver metabolism of periparturient cows associated with diseases in the transition period (Suthar et al., 2013). The primary novel finding of the current study was that Q supplementation was beneficial in periparturient cows because of the reduction in liver damage, which was indicated by increased plasma AST activities and a lower, although not significant, increase of plasma GLDH activities in the Q-treated group. Notably, the pp levels of plasma BHBA were lower, although not significant, in the Q-treated cows than in the CTR cows, an observation that supports our conclusion that Q had a beneficial effect on liver metabolism in periparturient cows because lower levels of BHBA in periparturient cows were associated with a lower risk of ketosis and hepatic lipidosis (Gonzales et al., 2011; Mostafavi et al., 2013). Nevertheless, we recognize that the CTR cows tended to have higher basal levels of plasma AST, but the extent to which the higher level might have affected AST levels pp is not clear. However, possible effects caused by the health of the cows in the CTR group on our findings cannot be excluded, and the observed Q effects must be viewed with caution. To confirm our observations, direct investigations of liver tissue are required to elucidate possible mechanisms of action. Additionally, these results should be verified in a larger number of cows.

We recognize that intraduodenal administration of $\mathrm{Q}$ is irrelevant in practical conditions. However, if a rumen-protected Q preparation became available that could be applied orally to pass through the rumen largely intact, the Q supplementation might provide benefits to alleviate liver disease in transition cows. Such a preparation could be rutin, a glucorhamnoside of $\mathrm{Q}$, which is not degraded in the rumen but leads to absorption of flavonoids, although rutin is not bioavailable when administered in the duodenum of cows (Berger et al., 2012; Gohlke et al., 2013a).

\section{CONCLUSIONS}

Our objective was to investigate the effect of $\mathrm{Q}$ on energy and lipid metabolism and milk production with a Q dose of $100 \mathrm{mg} / \mathrm{kg}$ of BW per day applied intraduodenally for $6 \mathrm{wk}$, beginning $3 \mathrm{wk}$ before parturition. In conclusion, we did not find any effect of $\mathrm{Q}$ on $\mathrm{EB}$, plasma metabolites, or performance in periparturient dairy cows, and the only effect was on the plasma activity of the liver enzyme AST. This lower activity of AST indicated that Q could have hepatoprotective effects. However, further studies are required to substantiate a potential beneficial effect of $\mathrm{Q}$ on hepatic health in periparturient dairy cows and to clarify the implications of these effects on animal performance.

\section{ACKNOWLEDGMENTS}

The authors are grateful to P. Schulz (Institute of Animal Nutrition and Physiology, Christian-AlbrechtsUniversity of Kiel), as well as to S. Dwars, K. Grot, C. Arlt, and S. Görs (Institute of Nutritional Physiology "Oskar Kellner," Leibniz Institute for Farm Animal Biology) for their excellent assistance in the laboratory. B. Stabenow, K.-D. Witt and his team, D. Oswald, T. Lenke, A. Schulz, and K. Pilz of the "Tiertechnikum" (Leibniz Institute for Farm Animal Biology, Institute of Nutritional Physiology "Oskar Kellner") are gratefully acknowledged for their assistance with animal care and Q supplementation. F. Schultz (Rinderallianz, Meckenburg-Vorpommern, Woldegk, Germany) and Q. L. Sciascia (Leibniz Institute for Farm Animal Biology, Institute of Nutritional Physiology "Oskar Kellner") are acknowledged for help with the selection of cows and language editing, respectively. This work was part of the joint research project Food Chain Plus (FoCus) under the funding initiative Kompetenznetze in der Agrar- und Ernaehrungsforschung and was financially supported by the Federal Ministry of Education and Research, Berlin, Germany (BMFT grant no. 0315538B).

\section{REFERENCES}

Ader, P., A. Wessmann, and S. Wolffram. 2000. Bioavailability and metabolism of the flavonol quercetin in the pig. Free Radic. Biol. Med. 28:1056-1067. http://dx.doi.org/10.1016/S08915849(00)00195-7. 
Aguirre, L., N. Arias, M. T. Macarulla, A. Gracia, and M. P. Portillo. 2011. Beneficial effects of quercetin on obesity and diabetes. Open Nutraceuticals J. 4:189-198.

Aikman, P. C., C. K. Reynolds, and D. E. Beever. 2008. Diet digestibility, rate of passage, and eating and rumination behavior of Jersey and Holstein cows. J. Dairy Sci. 91:1103-1114.

Bell, A. W. 1995. Regulation of organic nutrient metabolism during transition from late pregnancy to early lactation. J. Anim. Sci. 73:2804-2819.

Beltrán-Debón, R., A. Rull, F. Rodríguez-Sanabria, I. Iswaldi, M. Herranz-López, G. Aragonès, J. Camps, C. Alonso-Villaverde, J. A. Menéndez, V. Micol, A. Segura-Carretero, and J. Joven. 2011. Continuous administration of polyphenols from aqueous rooibos (Aspalathus linearis) extract ameliorates dietary-induced metabolic disturbances in hyperlipidemic mice. Phytomedicine 18:414424. http://dx.doi.org/10.1016/j.phymed.2010.11.008.

Berger, L. M., S. Wein, R. Blank, C. C. Metges, and S. Wolffram. 2012. Bioavailability of the flavonol quercetin in cows after intraruminal application of quercetin aglycone and rutin. J. Dairy Sci. 95:5047-5055. http://dx.doi.org/10.3168/jds.2012-5439.

Bobe, G., J. W. Young, and D. C. Beitz. 2004. Invited review: Pathology, etiology, prevention, and treatment of fatty liver in dairy cows. J. Dairy Sci. 87:3105-3124.

Börner, S., E. Albrecht, C. Schäff, S. Hacke, U. Kautzsch, M. Derno, H. M. Hammon, M. Röntgen, H. Sauerwein, and B. Kuhla. 2013. Reduced AgRP activation in the hypothalamus of cows with high extent of fat mobilization after parturition. Gen. Comp. Endocrinol. 193:167-177. http://dx.doi.org/10.1016/j.ygcen.2013.08.002.

Bremmer, D. R., S. L. Trower, S. J. Bertics, S. A. Besong, U. Bernabucci, and R. R. Grummer. 2000. Etiology of fatty liver in dairy cattle: Effects of nutritional and hormonal status on hepatic microsomal triglyceride transfer protein. J. Dairy Sci. 83:2239-2251.

Coffey, M. P., G. Simm, and S. Bortherstone. 2002. Energy balance profiles for the first three lactations of dairy cows estimated using random regression. J. Dairy Sci. 85:2669-2678. http://dx.doi. org/10.3168/jds.S0022-0302(02)74352-X.

Cozzi, G., L. Ravarotto, F. Gottardo, A. L. Stefani, B. Contiero, L. Moro, M. Brscic, and P. Dalvit. 2011. Short communication: Reference values for blood parameters in Holstein dairy cows: Effects of parity, stage of lactation, and season of production. J. Dairy Sci. 94:3895-3901. http://dx.doi.org/10.3168/jds.2010-3687.

Derno, M., H. G. Elsner, E.-A. Paetow, H. Scholze, and M. Schweigel. 2009. Technical note: A new facility for continuous respiration measurements in lactating cows. J. Dairy Sci. 92:2804-2808. http://dx.doi.org/10.3168/jds.2008-1839.

Derno, M., G. Nürnberg, P. Schön, A. Schwarm, M. Röntgen, H. M. Hammon, C. C. Metges, R. M. Bruckmaier, and B. Kuhla. 2013. Short-term feed intake is regulated by macronutrient oxidation in lactating Holstein cows. J. Dairy Sci. 96:971-980. http://dx.doi. org/10.3168/jds.2012-5727.

Djokovic, R., Z. Ilic, V. Kurcubic, and S. Jevtic. 2009. The functional state of liver cells in dairy cows during transition and lactation. Acta Agriculturae Serbica 27:53-61.

Djokovic, R., H. Samanc, M. Jovanovic, N. Fratric, V. Doskovic, and Z. Stanimirovic. 2013. Relationship among blood indicators of hepatic function and lipid content in the liver during transitional period in high-yielding dairy cows. Acta Sci. Vet. 41:1128.

Drackley, J. K. 1999. Biology of dairy cows during the transition period: The final frontier? J. Dairy Sci. 82:2259-2273.

Duffield, T. F., K. D. Lissemore, B. W. McBride, and K. E. Leslie. 2009. Impact of hyperketonemia in early lactation dairy cows on health and production. J. Dairy Sci. 92:571-580.

Dulloo, A. G., C. Duret, D. Rohrer, L. Girardier, N. Mensi, M. Fathi, P. Chantre, and J. Vandermander. 1999. Efficacy of a green tea extract rich in catechin polyphenols and caffeine in increasing $24-\mathrm{h}$ energy expenditure and fat oxidation in humans. Am. J. Clin. Nutr. 70:1040-1045.

Egert, S., G. Rimbach, and M. J. Müller. 2011. No evidence for a thermic effect of the dietary flavonol quercetin: A pilot study in healthy normal-weight women. Eur. J. Appl. Physiol. 111:869873. http://dx.doi.org/10.1007/s00421-010-1674-5.
Esposito, G., P. C. Irons, E. C. Webb, and A. Chapwanya. 2014. Interactions between negative energy balance, metabolic diseases, uterine health and immune response in transition dairy cows. Anim. Reprod. Sci. 144:60-71. http://dx.doi.org/10.1016/j. anireprosci.2013.11.007.

GfE (German Society of Nutrition Physiology). 2001. Ausschuss für Bedarfsnormen der Gesellschaft für Ernährungsphysiologie, No. 8. Empfehlungen zur Energie- und Nährstoffversorgung der Milchkühe und Aufzuchtrinder (Recommended energy and nutrient supply for dairy cows and growing cattle). DLG-Verlag Frankfurt am Main, Germany.

Goff, J. P., and R. L. Horst. 1997. Physiological changes at parturition and their relationship to metabolic disorders. J. Dairy Sci. 80:1260-1268.

Gohlke, A., C. J. Ingelmann, G. Nürnberg, A. Starke, S. Wolffram, and C. C. Metges. 2013a. Bioavailability of quercetin from its aglycone and its glucorhamnoside rutin in lactating dairy cows after intraduodenal administration. J. Dairy Sci. 96:2303-2313. http:// dx.doi.org/10.3168/jds.2012-6234.

Gohlke, A., C. J. Ingelmann, G. Nürnberg, J. M. Weitzel, H. M. Hammon, S. Görs, A. Starke, S. Wolffram, and C. C. Metges. 2013b. Influence of 4-week intraduodenal supplementation of quercetin on performance, glucose metabolism, and mRNA abundance of genes related to glucose metabolism and antioxidative status in dairy cows. J. Dairy Sci. 96:6986-7000. http://dx.doi.org/10.3168/ jds.2013-6852.

Gonzalez, F. D., R. Muino, V. Pereira, R. Campos, and J. L. Benedito. 2011. Relationship among blood indicators of lipomobilization and hepatic function during early lactation in high-yielding dairy cows. J. Vet. Sci. 12:251-255. http://dx.doi.org/10.4142/ jvs.2011.12.3.251.

Gross, J. J., F. J. Schwarz, K. Eder, H. A. van Dorland, and R. M. Bruckmaier. 2013. Liver fat content and lipid metabolism in dairy cows during early lactation and during a mid-lactation feed restriction. J. Dairy Sci. 96:5008-5017. http://dx.doi.org/10.3168/ jds.2012-6245.

Grummer, R. R. 1993. Etiology of lipid-related metabolic disorders in periparturient dairy cows. J. Dairy Sci. 76:3882-3896. http:// dx.doi.org/10.3168/jds.S0022-0302(93)77729-2 .

Harborne, J. B., and C. A. Williams. 2000. Advances in flavonoid research since 1992. Phytochemistry 55:481-504. http://dx.doi. org/10.1016/S0031-9422(00)00235-1.

Hoek-van den Hil, E. F., J. Keijer, A. Bunschoten, J. J. M. Vervoort, B. Stankova, M. Bekkenkamp, L. Herreman, D. Venema, P. C. H. Hollman, E. Tvrzicka, I. M. C. M. Rietjens, and E. M. van Schothorst. 2013. Quercetin induces hepatic lipid omega-oxidation and lowers serum lipid levels in mice. PLoS ONE 8:e51588 http:// dx.doi.org/10.1371/journal.pone.0051588.

Hursel, R., W. Viechtbauer, A. G. Dulloo, A. Tremblay, L. Tappy, W. Rumpler, and M. S. Westerterp-Plantenga. 2011. The effects of catechin rich teas and caffeine on energy expenditure and fat oxidation: A meta-analysis. Obes. Rev. 12:e573-e581. http://dx.doi. org/10.1111/j.1467-789X.2011.00862.x.

Jentsch, W., M. Derno, and O. Weiher. 2001. Heat production of dairy cows in dependence on milk yield-A study. Arch. Anim. Breed. 44:599-610.

Joven, J., E. Espinel, A. Rull, G. Aragonès, E. Rodríguez-Gallego, J. Camps, V. Micol, M. Herranz-López, J. A. Menéndez, I. Borrás, A. Segura-Carretero, C. Alonso-Villaverde, and R. Beltrán-Debón. 2012. Plant-derived polyphenols regulate expression of miRNA paralogs miR-103/107 and miR-122 and prevent diet-induced fatty liver disease in hyperlipidemic mice. Biochim. Biophys. Acta 1820:894-899. http://dx.doi.org/10.1016/j.bbagen.2012.03.020.

Jung, C. H., I. Cho, J. Ahn, T. Jeon, and T. Ha. 2013. Quercetin reduces high-fat diet-induced fat accumulation in the liver by regulating lipid metabolism genes. Phytother. Res. 27:139-143. http://dx.doi.org/10.1002/ptr.4687.

Kalaitzakis, E., N. Panousis, N. Roubies, N. Giadinis, E. Kaldrymidou, M. Georgiadis, and H. Karatzias. 2010. Clinicopathological evaluation of downer dairy cows with fatty liver. Can. Vet. J. $51: 615-622$. 
Kim, D. H., K. R. McLeod, J. L. Klotz, A. F. Foote, and D. L. Harmon. 2013. Evaluation of a rapid determination of fasting heat production and respiratory quotient in Holstein steers using the washed rumen technique. J. Anim. Sci. 91:4267-4276. http:// dx.doi.org/10.2527/jas.2012-5595

Klaus, S., S. Pultz, C. Thone-Reineke, and S. Wolffram. 2005. Epigallocatechin gallate attenuates diet-induced obesity in mice by decreasing energy absorption and increasing fat oxidation. Int. J. Obes. (Lond.) 29:615-623. http://dx.doi.org/10.1038/ sj.ijo.0802926.

Kobayashi, Y., M. Miyazawa, A. Kamei, K. Abe, and T. Kojima. 2010. Ameliorative effects of mulberry (morus alba 1.) leaves on hyperlipidemia in rats fed a high-fat diet: induction of fatty acid oxidation, inhibition of lipogenesis, and suppression of oxidative stress. Biosci. Biotechnol. Biochem. 74:2385-2395. http://dx.doi. org $/ 10.1271 /$ bbb.100392.

Lake, A. D., P. Novak, C. D. Fisher, J. P. Jackson, R. N. Hardwick, D. D. Billheimer, W. T. Klimecki, and N. J. Cherrington. 2011. Analysis of global and absorption, distribution, metabolism, and elimination gene expression in the progressive stages of human nonalcoholic fatty liver disease. Drug Metab. Dispos. 39:19541960 .

Landsberg, L. 2006. Feast or famine: The sympathetic nervous system response to nutrient intake. Cell. Mol. Neurobiol. 26:497-508.

Lesser, S., and S. Wolffram. 2006. Oral bioavailability of the flavonol quercetin. Curr. Top. Nutraceutical Res. 4:239-256.

Liu, P., B. X. He, X. L. Yang, X. L. Hou, H. Y. Zhao, Y. H. Han, P. Nie, H. F. Deng, and L. Cheng. 2012. Activities of aspartate aminotransferase, alanine aminotransferase, gamma-glutamyltransferase, alkaline phosphatase in plasma of postpartum Holstein cows. J. Anim. Vet Adv. 11:1270-1274.

Marcolin, E., L. F. Forgiarini, G. Rodrigues, J. Tieppo, G. S. Borghetti, V. L. Bassani, J. N. Picada, and N. P. Marroni. 2013. Quercetin decreases liver damage in mice with non-alcoholic steatohepatitis. Basic Clin. Pharmacol. Toxicol. 112:385-391. http://dx.doi. org $/ 10.1111 /$ bcpt.12049.

McArt, J. A. A., D. V. Nydam, and G. R. Oetzel. 2012. Epidemiology of subclinical ketosis in early lactation dairy cattle. J. Dairy Sci. 95:5056-5066. http://dx.doi.org/10.3168/jds.2012-5443.

McArt, J. A. A., D. V. Nydam, and M. W. Overton. 2015. Hyperketonemia in early lactation dairy cattle: A deterministic estimate of component and total cost per case. J. Dairy Sci. 98:2043-2054. http://dx.doi.org/10.3168/jds.2014-8740.

Merrell, M. D., and N. J. Cherrington. 2011. Drug metabolism alterations in nonalcoholic fatty liver disease. Drug Metab. Rev. 43:317-334. http://dx.doi.org/10.3109/03602532.2011.577781.

Mostafavi, M., H. A. Seifi, M. Mohri, and A. Jamshidi. 2013. Optimal thresholds of metabolic indicators of hepatic lipidosis in dairy cows. Revua Méd. Vet. (Kiev) 164:564-571.

Naumann, C., and R. Bassler. 1993. Method book III: The chemical analysis of feedstuffs. VDLUFA-Verlag, Darmstadt, Germany.

Nijveldt, R. J., E. van Nood, D. E. C. van Hoorn, P. G. Boelens, K. van Norren, and P. M. van Leeuwen. 2001. Flavonoids: A review of probable mechanisms of action and potential applications. Am. J Clin. Nutr. 74:418-425.

Ok, M., I. Sen, H. Guzelbektes, M. Boydak, C. Er, U. Aydogdu, and R. Yildiz. 2013. The importance of concentrations of sorbitol dehydrogenase and glutamate dehydrogenase and b-mode ultrasonographic examination in the diagnosis of hepatic lipidosis in dairy cows. Kafkas Univ. Vet. Fak. Derg. 19:A117-A123. http://dx.doi. org $/ 10.9775 / \mathrm{kvfd} .2012 .8146$.

Peres, W., M. J. Tunon, P. S. Collado, S. Herrmann, N. Marroni, and J. Gonzalez-Gallego. 2000. The flavonoid quercetin ameliorates liver damage in rats with biliary obstruction. J. Hepatol 33:742-750. http://dx.doi.org/10.1016/S0168-8278(00)80305-0.

Reist, M., D. Erdin, D. von Euw, K. Tschuemperlin, H. Leulenberger, Y. Chilliard, H. M. Hammon, C. Morel, C. Philipona, Y. Zbinden, N. Kuenzi, and J. W. Blum. 2002. Estimation of energy balance at the individual and herd level using blood and milk traits in highyielding dairy cows. J. Dairy Sci. 85:3314-3327. http://dx.doi org/10.3168/jds.S0022-0302(02)74420-2.

Rochfort, S., A. J. Parker, and F. R. Dunshea. 2008. Plant bioactives for ruminant health and productivity. Phytochemistry 69:299322. http://dx.doi.org/10.1016/j.phytochem.2007.08.017.

Staples, C. R., and W. W. Thatcher. 1990. Relationship between ovarian activity and energy status during the early postpartum period of high producing dairy cows. J. Dairy Sci. 73:938-947.

Stewart, L. K., J. L. Soileau, D. Ribnicky, Z. Q. Wang, I. Raskin, A. Poulev, M. Majewski, W. T. Cefalu, and T. W. Gettys. 2008 Quercetin transiently increases energy expenditure but persistently decreases circulating markers of inflammation in C57BL/6J mice fed a high-fat diet. Metabolism 57:S39-S46. http://dx.doi. org/10.1016/j.metabol.2008.03.003.

Suthar, V. S., J. Canelas-Raposo, A. Deniz, and W. Heuwieser. 2013 Prevalence of subclinical ketosis and relationships with postpartum diseases in European dairy cows. J. Dairy Sci. 96:2925-2938. http://dx.doi.org/10.3168/jds.2012-6035.

Thurmann, J.-P. 2012. Day variations of laboratory parameters of dairy cattle. PhD Thesis. Freie Universität, Berlin, Germany.

Vernon, R. G. 2005. Lipid metabolism during lactation: A review of adipose tissue-liver interactions and development of fatty liver. J. Dairy Res. 72:460-469. http://dx.doi.org/10.1017/ S0022029905001299.

Weber, C., C. Hametner, A. Tuchscherer, B. Losand, E. Kanitz, W. Otten, S. P. Singh, R. M. Bruckmaier, F. Becker, W. Kanitz, and H. M. Hammon. 2013. Variation in fat mobilization during early lactation differently affects feed intake, body condition, and lipid and glucose metabolism in high-yielding dairy cows. J. Dairy Sci 96:165-180. http://dx.doi.org/10.3168/jds.2012-5574.

Wein, S., and S. Wolffram. 2014. Concomitant intake of quercetin with a grain-based diet acutely lowers postprandial plasma glucose and lipid concentrations in pigs. Biomed. Res. Int. 2014:748742. http://dx.doi.org/10.1155/2014/748742. 